\title{
The Jurassic of Skåne, southern Sweden
}

\author{
Anders Ahlberg, Ulf Sivhed and Mikael Erlström
}

In Sweden, Jurassic strata are restricted to Skåne and adjacent offshore areas. Jurassic sedimentary rocks predominantly comprise sandy to muddy siliciclastics, with subordinate coal beds and few carbonate-rich beds. During Mesozoic times, block-faulting took place in the SorgenfreiTornquist Zone, a tectonic zone which transects Skåne in a NW-SE direction. The Jurassic depositional environments in Skåne were thus strongly influenced by uplift and downfaulting, and to some extent by volcanism. Consequently, the sedimentary record reveals evidence of numerous transgressions, regressions and breaks in sedimentation. Relative sea-level changes played a significant role in controlling the facies distribution, as deposition mainly took place in coastal plain to shallow shelf environments.

The alluvial deposits in Skåne include floodplain palaeosols, autochthonous coals, overbank sandstones, and stream channel pebbly sandstones. Restricted marine strata comprise intertidal heteroliths with mixed freshwater and marine trace fossil assemblages, and intertidal delta distributary channel sandstones. Shallow marine sediments encompass subtidal and shoreface sandstones with herringbone structures, and bioturbated mudstones with tempestite sandstones. Offshore deposits typically comprise extensively bioturbated muddy sandstones.

Floral remains, palaeopedology, clay mineralogy and arenite maturity indicate a warm and humid climate in Skåne throughout the Jurassic, possibly with slightly increasing aridity towards the end of the period. Most Jurassic strata in Skåne have been subjected to mild burial diagenesis, and the petroleum generative window has rarely been reached.

Keywords: Skåne, southern Sweden, Fennoscandian Border Zone, Danish Basin, Jurassic, lithostratigraphy, depositional environments, diagenesis

A.A., Department of Geology, Lund University, Sölvegatan 13, S-223 62 Lund, Sweden. E-mail: anders.ablberg@geol.lu.se U.S. \& M.E., Geological Survey of Sweden, Kiliansgatan 10, S-223 50 Lund, Sweden.

Jurassic sedimentary rocks in Sweden are restricted to Skåne (Scania), and adjacent offshore areas. They were deposited in areas separated by tectonic structural elements, each area reflecting different depositional and tectonic settings. The major areas are the Ängelholm Trough, the Helsingborg area, the Landskrona-Kävlinge area, south-west Skåne, central Skåne, the Vomb Trough and the Fyledalen Fault Zone (Fig. 1).

Skåne is situated at the transition between the Danish Basin to the south-west and landmasses including the Baltic Shield to the north-east. Therefore, small relative sea-level changes played a significant role in control- ling the lateral facies distribution. The Jurassic successions in Skåne comprise sediments that accumulated in coastal plain to shallow shelf environments.

The present distribution of Jurassic deposits in Skåne represents remnants of a once more extensive cover (Norling et al. 1993). Cretaceous-Cenozoic inversion resulted in significant erosion of the deposits once deposited within the Sorgenfrei-Tornquist Zone (Norling \& Bergström 1987; Erlström et al. 1997). Lower Jurassic deposits are by far the most widely preserved. They occur in troughs such as the Ängelholm Trough, the Landskrona-Kävlinge area, south-west Skåne includ- 


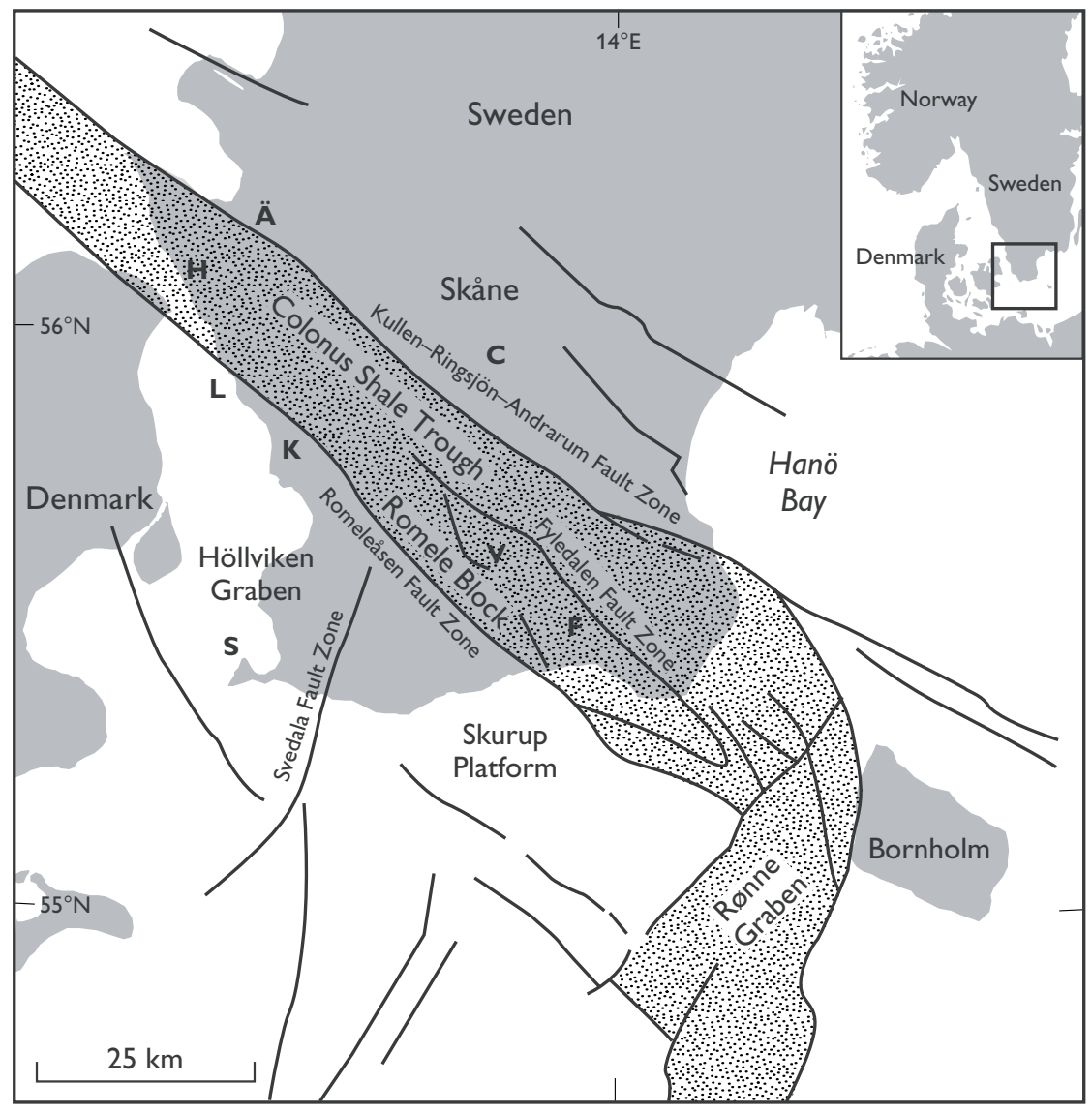

Fig. 1. Major tectonic elements of Skåne, after Erlström et al. (1997). Stippled area indicates the Sorgenfrei-Tornquist Zone, at the transition from the Baltic Shield in the north-east to the Danish Basin in the south-west.

Ä, Ängelholm Trough;

C, central Skåne;

F, Fyledalen Fault Zone;

H, Helsingborg area;

$\mathbf{K}$, Kävlinge area;

L, Landskrona area;

S, SW Skåne;

V, Vomb Trough.

For additional outcrop and core loca-

tions, see Sivhed (1984) and Norling et al. (1993).

ing the Höllviken Graben, the Hanö Bay Basin, the Vomb Trough and the Fyledalen Fault Zone, and as erosional remnants on Precambrian basement in central Skåne. The Rhaetian - Lower Jurassic succession is up to $250 \mathrm{~m}$ in thickness (Sivhed 1984), whereas the Middle and Upper Jurassic sediments are 75-300 m thick (Norling 1972; Norling et al. 1993).

In Skåne, most information on Jurassic strata comes from the Helsingborg area (Norling 1972; Sivhed \& Wikman 1986; Norling \& Wikman 1990) and in the Fyledalen Fault Zone, where relatively well-exposed sections occur (Norling et al. 1993). In other areas, the development of the Jurassic is incompletely known. Results presented by Vossmerbäumer (1969, 1970), Rolle et al. (1979), Ahlberg (1990, 1994), Erlström et al. (1991, 1994), Pieńkowski (1991a, b) and Arndorff (1994) have added to the understanding of the depositional conditions and the relationship between the different areas of deposition.

The aim of the present paper is to give an overview of the work hitherto done on the stratigraphy and sedimentology of the onshore Jurassic strata in Skåne, including previously unpublished discoveries and ideas.

\section{Structural framework}

Throughout the Jurassic, block faulting played a significant role in Skåne. The faulting was strongly influenced by major plate tectonic events, i.e., the break-up of Pangea, the closing of Tethys and the opening of the North Atlantic (Ziegler 1990). The Early Alpine tectonic phases in Northwest Europe resulted in the activation of the Tornquist Zone along lineaments established during the Palaeozoic (Norling \& Bergström 1987; Erlström et al. 1997). The Tornquist Zone (Fig. 1) is subdivided into the Sorgenfrei-Tornquist and TeisseyereTornquist Zones (see discussions in Liboriussen et al. 1987; Norling \& Bergström 1987; EUGENO-S Working Group 1988; Berthelsen 1992; Michelsen \& Nielsen 1993; Thomas et al. 1993; Thybo et al. 1994; Erlström et al. 1997; Vejbæk 1997). The Sorgenfrei-Tornquist Zone links with the Rønne Graben and continues north-westwards through Skåne to the northwestern part of Jylland. The Teisseyere-Tornquist Zone extends south-east from the Rønne Graben into Poland.

In general, tectonism actively controlled deposition and erosion in Skåne throughout the Jurassic, leaving 
different patterns of deposition and lacunas in individual tectonic blocks. Major structural elements include the Romele Block, the Höllviken Graben, the Colonus Shale Trough and the Ängelholm Trough. Major faults include the Kullen-Ringsjön-Andrarum Fault Zone, the Fyledalen Fault Zone, the Romeleåsen Fault Zone and the Svedala Fault Zone (Fig. 1; Thomas et al. 1993; Erlström et al. 1997).

Parts of the Romele Block, including the Vomb Trough (formed in the Late Cretaceous), were subjected to erosion and non-deposition during the late Middle Jurassic, while others persisted as depocentres. Within the Fyledalen Fault Zone, Jurassic deposits are tilted or overturned due to uplift of the Colonus Shale Trough (Norling \& Bergström 1987; Erlström et al. 1997). In the Colonus Shale Trough, most Triassic and Jurassic deposits were removed by erosion associated with the Late Cretaceous - Neogene inversion tectonics of the Sorgenfrei-Tornquist Zone. A similar development has been observed in the Rønne Graben, which indicates the existence of a linked graben structure superimposed on the Tornquist Zone during much of the Jurassic (Vejbæk 1985; Thomas \& Deeks 1994; Vejbæk et al. 1994; Erlström et al. 1997).

\section{Depositional development}

In Skåne, Upper Triassic (Norian) fining-upwards cycles of coarse-grained, alluvial fan deposits grade upwards and basinwards into smectite-rich siltstones and mudstones, in which caliche nodules and halite pseudomorphs have been found (Arndorff 1994). At the onset of the Rhaetian, mineralogically mature, coal-bearing, kaolinite-rich siliciclastics were deposited, reflecting a regional change from warm semi-arid to warm and humid conditions, and an accompanying reduction in relief. The humidity was enhanced by the opening of interior seaways by rifting (Manspeizer 1994). These climatic conditions dominated in Skåne in the Jurassic (Hallam 1994).

The Lower Jurassic deposits in Skåne accumulated during a relatively quiet tectonic period, with a regional downwarp towards the depocentres of the Danish Basin (Norling \& Bergström 1987). The succession in northwestern Skåne is characterised by Rhaetian-Hettangian coastal plain to deltaic sediments succeeded by shallow marine deposits of Sinemurian-Aalenian age. In central Skåne, Rhaetian-Hettangian sediments unconformably overlie deeply weathered Precambrian gneiss. Volcanic necks and associated pyroclastic deposits occur in central Skåne (Norin 1933); these have been dated to the Early Jurassic - Middle Jurassic transition (Tralau 1968, 1973; Bylund \& Halvorsen 1993).

As a result of Middle Jurassic rifting in the North Sea (Ziegler 1990), tectonic unrest was transferred to Skåne, which was subjected to uplift (Norling \& Bergström 1987). Marine influence ceased, and most of Skåne was subjected to erosion which probably removed much of the Lower Jurassic succession. However, in certain areas (e.g. Ängelholm Trough and the Fyledalen Fault Zone), deposition continued in coastal plain to shallow marine environments.

During the Late Jurassic, new marine transgressions affected Skåne (Norling \& Bergström 1987). Coastal and shallow marine sediments of Oxfordian age were deposited, after a period of rapid facies changes in the late Middle Jurassic (Norling 1981; Norling \& Bergström 1987; Erlström et al. 1997). After a period of relative quiescence, tectonic activity in Skåne increased again at the Jurassic-Cretaceous transition, which led to reactivation (inversion) of pre-existing fault systems (Erlström et al. 1997).

In general, a warm and humid climate prevailed in Skåne and adjacent areas during much of the Jurassic (Hallam 1994; Manspeizer 1994), and vegetation largely covered coastal plains, which resulted in the formation of autochthonous coal beds. These conditions also favoured low-pH chemical weathering in the hinterlands, along sediment transport paths and during pedogenesis. Therefore, Jurassic strata in Skåne include mineralogically mature sandstones, and clay mineral suites with a considerable content of kaolinite. In the Late Jurassic, the region was subjected to increasing aridity which caused very limited evaporite mineral formation in Skåne (caliche nodules).

\section{Lithostratigraphy}

The lithostratigraphic scheme of the Jurassic succession in Skåne (Fig. 2) was established by Norling (1972, 1981), Sivhed (1984) and Norling et al. (1993). The Jurassic successions are subdivided into the Höganäs, Rya and Annero Formations and the informal Mariedal formation (Fig. 2; Norling et al. 1993). Exceptions to this do occur. In central Skåne, the Rhaetian-Hettangian is referred to the Höör Sandstone, which in places is overlain by lithostratigraphically unspecified sediments. In the Ängelholm Trough, the Middle Jurassic is referred to the Vilhelmsfält Formation; in the Fyledalen Fault Zone, the Lower Jurassic is referred to the informal 


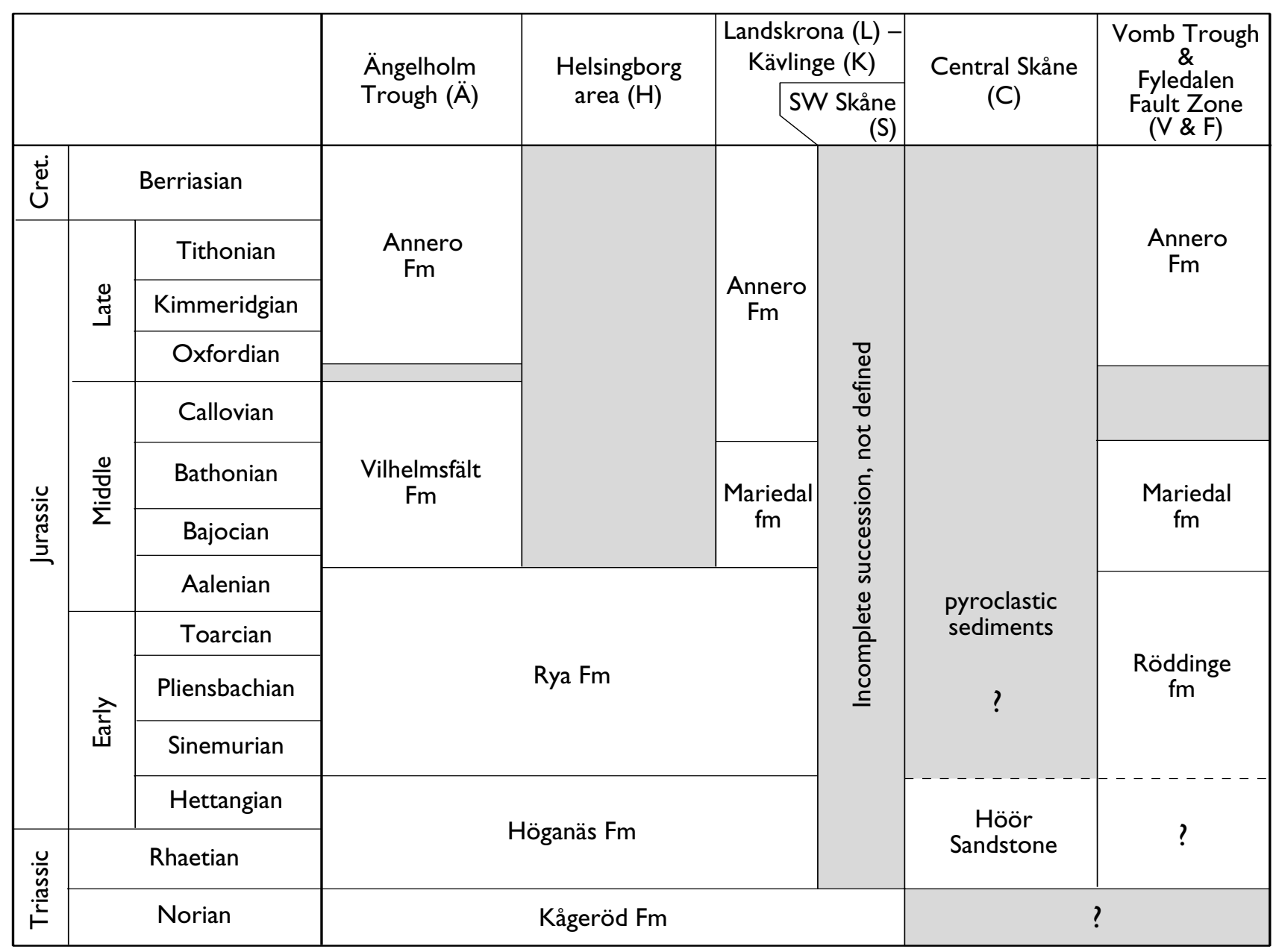

Fig. 2. Lithostratigraphic scheme of the Jurassic of Skåne, modified from Norling et al. (1993). The localities are indicated on Fig. 1.

Röddinge formation. In the subsurface of south-west Skåne, an incomplete succession of Jurassic strata ranging from the Aalenian to the Tithonian has been recorded. This resembles exposed penecontemporaneous strata fairly well, and it is thought likely that parts of the Höganäs, Rya and Annero Formations are represented, at least in part, in south-west Skåne (Norling 1981; D. Guy-Ohlson, personal communication 1994).

\section{Höganäs Formation}

\section{Stratigraphy and distribution}

The Höganäs Formation constitutes a transitional unit between the continental Kågeröd Formation and the shallow marine Rya Formation. The formation is wellknown and well-defined in the Helsingborg area (Sivhed 1984; Figs 1, 2). It can be traced in deep wells in south- west Skåne (Brotzen 1950; Larsson et al. 1994) and it is also represented on the Skurup Platform (Thomas et al. 1993). The plant-bearing sediments at Rödalsberg and Munka Tågarp in the Fyledalen Fault Zone (Möller \& Halle 1913) are here tentatively referred to the Höganäs Formation. It is possible that the members of the Höor Sandstone in central Skåne can be correlated to similar strata of the Höganäs Formation (Troedsson 1951). The Höganäs Formation is up to $250 \mathrm{~m}$ thick in the Helsingborg area (Sivhed \& Wikman 1986), $150 \mathrm{~m}$ in the Ängelholm area (Bölau 1959), $40 \mathrm{~m}$ in the Svedala area (Larsson et al. 1994) and probably more than $150 \mathrm{~m}$ in the Höllviken area. Palynomorph dating of the Höganäs Formation indicates a Rhaetian-Hettangian age (Lund 1977; Guy-Ohlson 1981). In the Ängelholm Trough and in the Helsingborg area, the Höganäs Formation is subdivided into the Vallåkra and Bjuv Members (Rhaetian) and the Helsingborg Member (Hettangian). 


\section{Sedimentology and petrography}

The Vallåkra Member has been reported to comprise poorly stratified kaolinitic and smectitic mudstones and sandstones with sphaerosiderite concretions; the upper parts of the Vallåkra Member have yielded a restricted marine fauna (Troedsson 1948, 1951).

The Bjuv Member is bounded below and above by extensive autochthonous coals. Coals, kaolinitic mudstones, heteroliths (flaser and lenticular bedded sandstones and mudstones) and mineralogically mature arenites are common in this member (Ahlberg 1994; Arndorff 1994). The Bjuv Member is dominated by floodplain deposits, including mature palaeosols (stacked underclays and autochthonous coals), interbedded with isolated fluvial channel and crevasse splay sandstones (Ahlberg 1994; Arndorff 1994). In these sediments, numerous dinosaur footprints have been observed (Bölau 1952; Gierlinski \& Ahlberg 1993). In addition, sparse evidence of marine influence on the floodplains has been observed, indicating a coastal plain setting. The marine signatures include heteroliths with Rbizocorallium isp. and Diplocraterion isp. burrows (Ahlberg 1994) and dinoflagellates (S. Lindström, personal communication 1996).

The Höganäs Formation has traditionally been referred to as deltaic, including 12 deltaic cycles. Nine of these are found in the uppermost member, the Helsingborg Member (Troedsson 1950, 1951). This stratigraphic unit includes floodplain strata similar to those of the Bjuv Member. Here, however, the floodplains were subjected to several restricted marine incursions (Vossmerbäumer 1969, 1970; Ahlberg 1990, 1994; Pieńkowski 1991a, b). These are testified by the presence of molluscs, foraminifera (very rare), a well-developed partly marine trace fossil assemblage (Fig. 3A), and indications of tidal activity. The tidal signatures include abundant bioturbated muddy heteroliths, which locally show bimodal
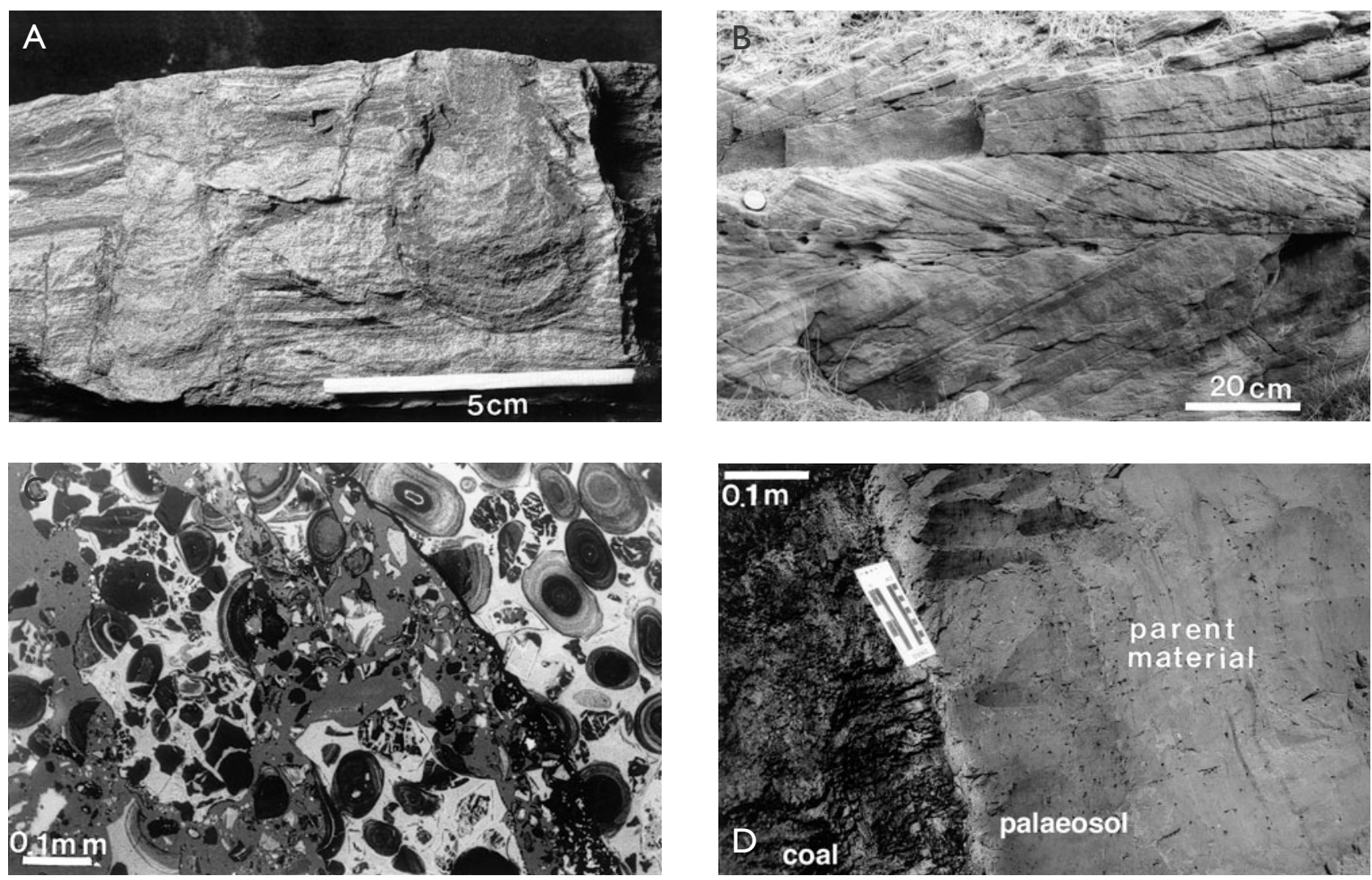

Fig. 3. Features of the Höganäs (A), Rya (B, C) and Mariedal (D) formations. A: Two Diplocraterion isp. burrows associated with rootlets in a muddy heterolith (Helsingborg Member, Helsingborg railway tunnel), representing mixed marine and non-marine bioturbation in a mudflat. B: Herringbone structures in marine sandstone (Döshult Member, Laröd road section). C: Backscatter electron image of berthierine ooids in thin section (Rydebäck Member, drill core Rydebäck-Fortuna 4, at a depth of 67.20 m). D: Overturned autochthonous coal bed with pyrite concretions, overlying pedogenically altered sand with rootlets. The parent material (i.e. the light sand without pedogenic overprint to the right) includes Diplocraterion isp. burrows. The section probably records infilling of an interdistributary bay and subsequent stabilisation by peat. Photo from the top of the Fuglunda Member, Eriksdal sand quarry. 


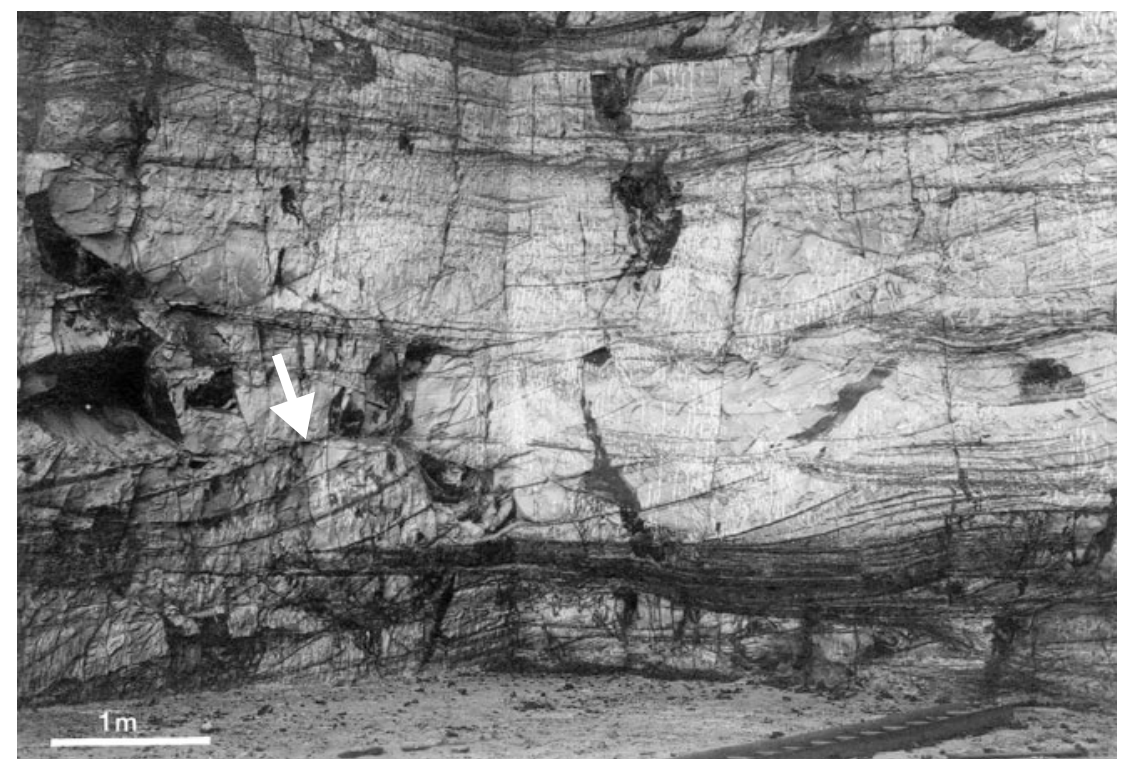

Fig. 4. Muddy heteroliths and sandy foreset beds with rhythmically spaced mud drapes (arrow) in the Helsingborg Member. These deposits probably represent bedforms that migrated into an intertidal interdistributary bay. Pauses in foreset migration and subsequent mud draping occurred during tidal slackwater (Sellwood 1972; Terwindt 1981; Tyge 1990). Section exposed temporarily in 1928 in the centre of Helsingborg; photo from the collection of $\mathrm{G}$. Troedsson.

ripple orientation and scoured sand-filled channels. In addition, cosets of cross-bedded sandstones with rhythmically spaced mud drapes and reactivation surfaces have been observed, which indicate uniform westwards (basinwards) sediment transport, possibly in tidallyinfluenced delta distributary channels (Fig. 4).

The overall facies architecture of the Höganäs Formation in north-west Skåne is dominated by floodplain or muddy bay deposits, which encase laterally restricted sandstone bodies (Troedsson 1951; Ahlberg 1994). This is suggestive of a high and constant rate of subsidence and vertical sediment accretion (and availability of accommodation space).

Tabular basinwide sandstone bodies have been described at two levels within the Helsingborg Member (Troedsson 1951). One of these occurs at the base of the Hettangian succession, where Rhaetian overbank sediments are abruptly followed by Hettangian gravel and sand deposited in braided rivers. This change may have been caused by hinterland uplift (Troedsson 1951), but could also reflect the upstream effects of a relative sea-level fall in the Danish Basin. A maximum flooding surface has been recognised in the Upper Rhaetian of the Danish Basin, overlain by a sequence boundary and a Lower Hettangian lowstand systems tract. This low sea-level stand induced basinwards progradation of lowstand shoreface sand, from the margins towards the depocentres of the Danish Basin (Nielsen 1994; Nielsen 2003, this volume). Such a lowering in stratigraphic base level may have increased the alluvial slope, and triggered the Early Hettangian onset of braided stream deposition recorded in north-west Skåne (Ahlberg 1994; see Posamentier et al. 1992; Shanley \& McCabe 1994). In addition, an abrupt increase in surface runoff could have caused a similar depositional pattern (Ahlberg 1994).

\section{Höör Sandstone}

\section{Stratigraphy and distribution}

The Höör Sandstone crops out in the central part of Skåne (Fig. 1), where it forms erosional remnants directly overlying weathered Precambrian crystalline basement. The $50 \mathrm{~m}$ thick formation is of Rhaetian-Hettangian age, according to its macro- and microflora (Antevs 1919; Troedsson 1940; Lund 1977). The threefold division includes a lower unnamed unit, up to $15 \mathrm{~m}$ thick, overlain by the Stanstorp Member (up to $15 \mathrm{~m}$ thick; local term: 'kvarnstenen' = millstone). The uppermost member, the Vittseröd Member (up to $25 \mathrm{~m}$ thick; local term: 'byggnadsstenen' = building stone), is exposed in several abandoned quarries south-east of Höör (Norling et al. 1993; Wikman \& Sivhed 1993).

\section{Sedimentology and petrography}

The Höör Sandstone outcrops are only a few $\mathrm{m}^{2}$ in size, thus precluding detailed interpretation of depositional setting. The basal unit is presently not exposed, but has been reported to comprise fine-grained sandstones, mudstones and clays (Wikman \& Sivhed 1993). 
The middle unit, the Stanstorp Member, is composed of arkoses, subarkoses and quartz arenites. Polymict conglomerates, mudstones and thin coal laminae occur in the unit, and impressions of fossil wood are abundant (Troedsson 1940). Sedimentary structures include large-scale cross-bedding, cut and fill structures, and a thin, graded event layer with an erosional basal conglomerate and superimposed current ripples, indicating waning energy conditions. A tentative interpretation of the sediments of the Stanstorp Member is that they were deposited in a continental environment subjected to floods (G. Pieńkowski, personal communication 1988).

The uppermost unit, the Vittseröd Member, consists of fine-grained, quartz-cemented quartz arenites and subarkoses. Texturally, the sandstones are fairly mature and they have probably been thoroughly reworked by waves and currents. Sedimentary structures include trough cross-bedding, which in places form herringbone structures, and rip-up mud clasts on bedding surfaces. Plant fragments are not as common as in the Stanstorp Member, and beds rich in bivalve impressions have been reported (Troedsson 1940). The member probably consists of nearshore marine sediments, surrounding islands of weathered Precambrian gneiss, forming an archipelago (Norling et al. 1993).

\section{Rya Formation}

\section{Stratigraphy and distribution}

The marine Rya Formation (Fig. 2) is subdivided, from base to top, into the Döshult, Pankarp, Katslösa and Rydebäck Members. The formation is recognised in the Ängelholm, Helsingborg, Landskrona and Kävlinge areas. In south-west Skåne, the Rya Formation is missing or only poorly developed (Norling \& Skoglund 1977; Norling 1981, 1982; Larsson et al. 1994). Based on foraminifers, ammonites and ostracodes, the Döshult Member is dated to the Early Sinemurian, the Pankarp Member to the Late Sinemurian, the Katslösa Member to the Late Sinemurian - Early Pliensbachian and the Rydebäck Member to the Late Pliensbachian - Late Aalenian (Reyment 1969; Norling 1972; Sivhed 1980, 1984).

\section{Sedimentology and petrography}

The Döshult Member is characterised by coarse-grained sandstones and siltstones in the lower part, and is dominated by clays and marls rich in marine fossils in the upper part. The member is up to $80 \mathrm{~m}$ thick in the Ängelholm, Helsingborg and Landskrona areas (Bergström et al. 1982). At present, the basal part of this member is exposed at three localities in the Helsingborg area (for locations, see Norling et al. 1993). These contain mineralogically and texturally mature, trough crossbedded sandstones, commonly with herringbone structures showing north and south oriented palaeocurrent directions (Fig. 3B). The occurrence of herringbone structures in well-sorted sand (tidal or not) suggests high energy foreshore to subtidal marine depositional conditions for the lower part of the member. In an abandoned quarry in north-west Skåne (Gantofta brickpit in the Helsingborg area, outcrop very limited at present) the upper part of the Döshult Member commences with bioturbated marine nearshore sands, including Diplocraterion isp., Rhizocorallium isp., Chondrites isp. and Planolites isp. burrows, as well as abundant marine invertebrate body fossils (Frandsen \& Surlyk 2003, this volume). This is followed by a bioturbated shelf mudstone with storm-deposited sand and silt intercalations (tempestites). A massive red mudstone with scarce marine body fossils and burrows follows, which is interpreted as having been deposited rapidly, in a low energy but oxidising environment. The youngest part of the succession comprises siltstones and mudstones, with carbonate-rich beds, deposited in a shallow marine setting (Rolle et al. 1979).

The Pankarp Member has an estimated thickness of up to $70 \mathrm{~m}$ in the subsurface of the Ängelholm, Helsingborg and Landskrona areas. In the Kävlinge area, the thickness is about $20 \mathrm{~m}$ (Sivhed 1980; Norling 1981; Norling et al. 1993). In westernmost Skåne, the Pankarp Member has been observed in small diameter drill cores. There, the member is subdivided into a lower unit of variegated clays and shales, a middle, poorly sorted silty to sandy unit including a coal bed, and an upper monotonous mudstone unit which is silty and organicrich at the base, and reddish-greenish at the top (Sivhed 1980; Norling et al. 1993). In the uppermost part of one core, the Pankarp Member comprises lenticular bedded heteroliths with Planolites isp. burrows.

The Katslösa Member is mainly known from the subsurface in westernmost Skåne, and it has a thickness of 30-40 m in the Ängelholm, Helsingborg and Landskrona areas. In the Kävlinge area, the thickness is about 75 m (Sivhed 1980; Norling 1981; Norling et al. 1993). The most complete section, at Katslösa in the Helsingborg area, was described and sampled by Troedsson (1951), as he followed a temporary trench dug perpendicular to the strike of the tilted strata. Sedimento- 
logical interpretations given here are mainly based on the results of recent petrographical studies of museum collections, combined with published lithological descriptions (Troedsson 1951; Norling 1972). The Katslösa Member yields a rich marine microfauna and macrofauna, and it is dominated by homogeneous mudstone deposited in a marine low-energy environment. Thin beds of matrix-rich quartz wackes are common. They are typically mineralogically mature but texturally highly immature with abundant angular sand grains. The matrix comprises organic matter, micrite, mica and clay minerals. In thin section, the sandstones show evidence of intense burrowing, which has obliterated depositional structures. Scattered berthierine ooids, as well as authigenic siderite crystals have been observed.

The Rydebäck Member is up to $70 \mathrm{~m}$ thick in the Ängelholm, Helsingborg and Landskrona areas. It is only known from subsurface material in westernmost Skåne, and sedimentological conclusions herein are entirely based on observations from two wells (drill cores Rydebäck-Fortuna-1 and -4). The member comprises a uniform succession of muddy arenites with a rich marine microfauna (mostly foraminifera), and represents deposition in an offshore low-energy environment (Norling 1972). The sediments are strongly burrowed, which has caused an effective mixing of sand and mud, resulting in the forming of quartz wackes. The sand is quartz-rich, and grains are typically well rounded. Berthierine ooids are common constituents of the sediment (Fig. 3C).

In conclusion, deposition of the Rya Formation began with nearshore coarse clastics, and continued with offshore mudstones with tempestites (the Döshult Member), followed by offshore muddy sediments with a brief nonmarine interval (the Pankarp Member), and ended with deposition of open marine low-energy deposits (the Katslösa Member and the Rydebäck Member). Hence, the marine Rya Formation shows an overall fining-upwards trend, and an up-section bathymetric deepening of the depositional environment. It is notable that the stormdominated, hummocky cross-stratified Hasle Formation on Bornholm is contemporaneous with the muddy Katslösa Member of the Rya Formation (Surlyk \& NoeNygaard 1986; Koppelhus 1995). The depositional environment in western Skåne was either physically protected from the storm energy due to basin topography, or deposition in Skåne took place below storm wavebase.

Berthierine ooids occur scattered in the Katslösa Member and are increasingly abundant up-section in the Rydebäck Member. There is an intriguing possibility that iron ooid formation was promoted by precipi- tation of iron and silica from volcanic exhalative fluids rising up through the substrate, as has been reported from modern marine sediments offshore Indonesia (Heikoop et al. 1996). This hypothesis has emerged with the recent publication of new age data for the volcanic rocks in Skåne, which now appear to be comparable in age to the prominent iron ooid-bearing deposits, i.e. the Rydebäck Member and the Röddinge formation (see below).

\section{Röddinge formation}

\section{Stratigraphy and distribution}

Due to the limited degree of exposure and the weathered state of the surficial strata, the informal stratigraphic unit 'Röddinge formation' was introduced for the iron-rich deposits in the Fyledalen Fault Zone, primarily at Kurremölla (Norling et al. 1993).

The Röddinge formation is largely known from museum collections, and it has been dated by ammonite biostratigraphy to be of Sinemurian-Pliensbachian age (Moberg 1888; Reyment 1959). Based on unpublished museum data (sample locations, etc.), it is calculated that the Röddinge formation has a thickness of several hundreds of metres.

\section{Petrography}

The Röddinge formation is dominated by fine- to medium-grained quartz arenites, with subordinate thin conglomerates. The sediments are moderately consolidated by berthierine or siderite cement, and berthierine oolites are common in the succession. The ooids are generally around $0.3 \mathrm{~mm}$ in diameter and ellipsoidal in shape. The core commonly consists of detrital quartz or heavy minerals, surrounded by concentric microlaminae of berthierine. The deposits are strongly affected by modern weathering and are characterised by a red, brown or yellow stain (iron hydroxides). Unweathered deposits, known from boreholes, are greyish dark green due to the content of berthierine and siderite. The iron content is $8-10 \%$ in the weathered sandstones, up to $20 \%$ in the oolites, and at Kurremölla a $1.7 \mathrm{~m}$ thick oolite bed has an iron content of up to $35 \%$. This ore bed was mined during the 1930s (Hadding 1933).

Due to the poor, weathered exposure, the Röddinge formation has not been subjected to detailed facies 
analysis. In general, the mineralogical and textural maturity of the sands imply prolonged reworking. Marine influence is clearly indicated by finds of ammonites and crinoids (Hadding 1933).

The shape of the iron ooids indicate diagenetic precipitation, prior to and during sediment compaction. As discussed above with respect to the berthierine ooids in the Rydebäck and Katslösa Members, volcanic activity may have stimulated the process. Lateritisation has been suggested as another possible source for the iron enrichment in the sediments (Nilsson 1992).

\section{Vilhelmsfält Formation and Mariedal forma- tion}

\section{Stratigraphy and distribution}

Middle Jurassic sediments are found in parts of western Skåne, in the Fyledalen Fault Zone and in the Ängelholm Trough. The deposits are divided into two formations, the Vilhelmsfält Formation and the Mariedal formation (Norling et al. 1993). The Vilhelmsfält Formation is restricted to the Ängelholm Trough. It has been dated as Bajocian-Bathonian on palynological grounds (Guy-Ohlson 1971, 1986, 1989). Similarities between the Vilhelmsfält Formation and the Fuglunda Member of the Mariedal formation were noted by Bölau (1959), but such a correlation cannot be confirmed at present. Use of the informal name 'Mariedal formation' was recommended by Norling et al. (1993), until the identity of the formation is resolved. The Mariedal formation crops out in the Fyledalen Fault Zone, and is also found in the Landskrona and Helsingborg areas (Fig. 1). It has been divided into the Fuglunda Member and the overlying Glass Sand Member, which are dated to the Bajocian and the Bathonian, respectively, on palynological and palaeobotanical grounds (Tralau 1966, 1968). The Fuglunda Member is up to $75 \mathrm{~m}$ thick, whereas the Glass Sand Member has a thickness of up to $100 \mathrm{~m}$ (Norling et al. 1993).

\section{Lithology of the Vilhelmsfält Formation}

The Vilhelmsfält Formation consists mainly of sandy, micaceous mudstones with plant remains and sandy intercalations. A thin coal bed has been observed in a sandy layer in the lower part of the formation. The formation is more than $75 \mathrm{~m}$ thick (Bölau 1959).
Lithology and sedimentology of the Mariedal formation

In a quartz sand quarry at Eriksdal in the Fyledalen Fault Zone, the Fuglunda Member comprises thirteen deltaic cycles of coals, heteroliths and sandstones (Koch 1979; Rolle et al. 1979). The coals are commonly associated with rootlet horizons and immature palaeosols (Fig. 3D). Hence, they were formed autochthonously, primarily by in-situ accumulation of wood in peat swamps. Indeed, between each coal bed, several soil formation 'attempts' (i.e. immature palaeosols) may be distinguished. The palaeosols differ clearly from their parent material in terms of colour, texture and degree of stratification. Typically, the lower boundaries are gradational, and the upper boundaries are sharp. Rooting and eluviation of clay minerals and organic matter are additional pedogenic characteristics (Allen \& Wright 1989).

The heteroliths include the full spectrum from almost pure mudstone (rich in clay-sized coal detritus) with slightly lenticular silt laminae, through lenticular, wavy and flaser bedded heteroliths. A partly marine trace fossil assemblage is characteristic of the heteroliths, including Diplocraterion isp. and Monocraterion isp. The bioturbated muddy heteroliths interfinger with sandy heteroliths, autochthonous coals and palaeosols. They were probably deposited in intertidal low energy environments, i.e. interdistributary bays (Rolle et al. 1979). Abundant large $(<10 \mathrm{~cm})$ pyrite concretions occur in the coals and the organic-rich heteroliths, implying a marine influence on the eodiagenesis (Curtis \& Coleman 1986). Flaser bedded, sandy heteroliths commonly show trough cross-bedding, mud drapes, climbing ripples and channel scour. This facies probably represents deposition in tidal channels. In the Eriksdal quarry, a coarse-grained, pebbly sandstone showing scour-andfill structures, forms a lenticular body encased in the coals and heteroliths of the Fuglunda Member. This facies probably represents a delta distributary channel fill. In conclusion, the Fuglunda Member at Eriksdal shows typical features of a delta plain environment.

The Glass Sand Member (up to $100 \mathrm{~m}$ thick) succeeds the Fuglunda Member in the Eriksdal quartz sand quarry. The sediments consist predominantly of coarse- and fine-grained sandstone (or sand), with minor intercalations of heteroliths and mudstone with Diplocraterion isp. burrows (Rolle et al. 1979). Differing interpretations have been offered for the depositional setting of these sediments. The member was described by Rolle et al. (1979) as being of foreshore and lagoonal origin. 

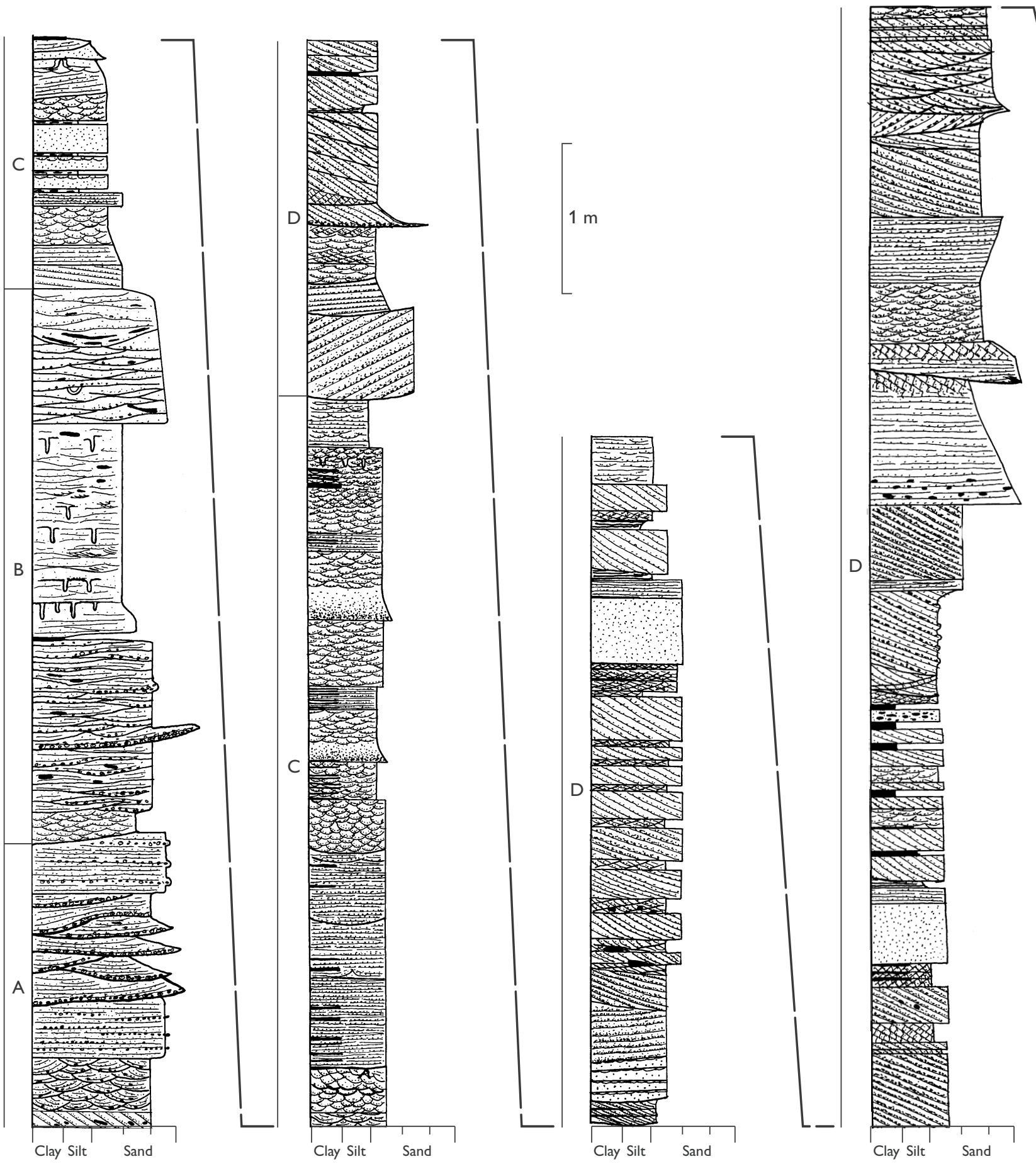

Fig. 5. Log from the Glass Sand Member at Eriksdal (J. Johansson and L. Adrielsson, personal communication 1998). A, shallow stream or unconfined flow (sheet flood) deposits from crevasse splays close to an active channel; $\mathbf{B}$, distal crevasse splay deposits in extremely shallow interdistributary bay (or floodplain) area; C, turbiditic deposition in standing water, probably by subaqueous overbank floods; D, distributary channel deposits showing two-dimensional dunes with superimposed ripples, three-dimensional dunes and cross-channel bars implying unidirectional flow; $\mathbf{E}$, channel erosion and lateral migration with slump sediments (massive sand and large peat (coal) balls, i.e. reworked floodplain swamp deposits) from river bank collapse; $\mathbf{F}$, channel fill deposits dominated by ripple-laminated sand, fining-upwards; $\mathbf{G}$, channel fill concluded and establishment of flora. 


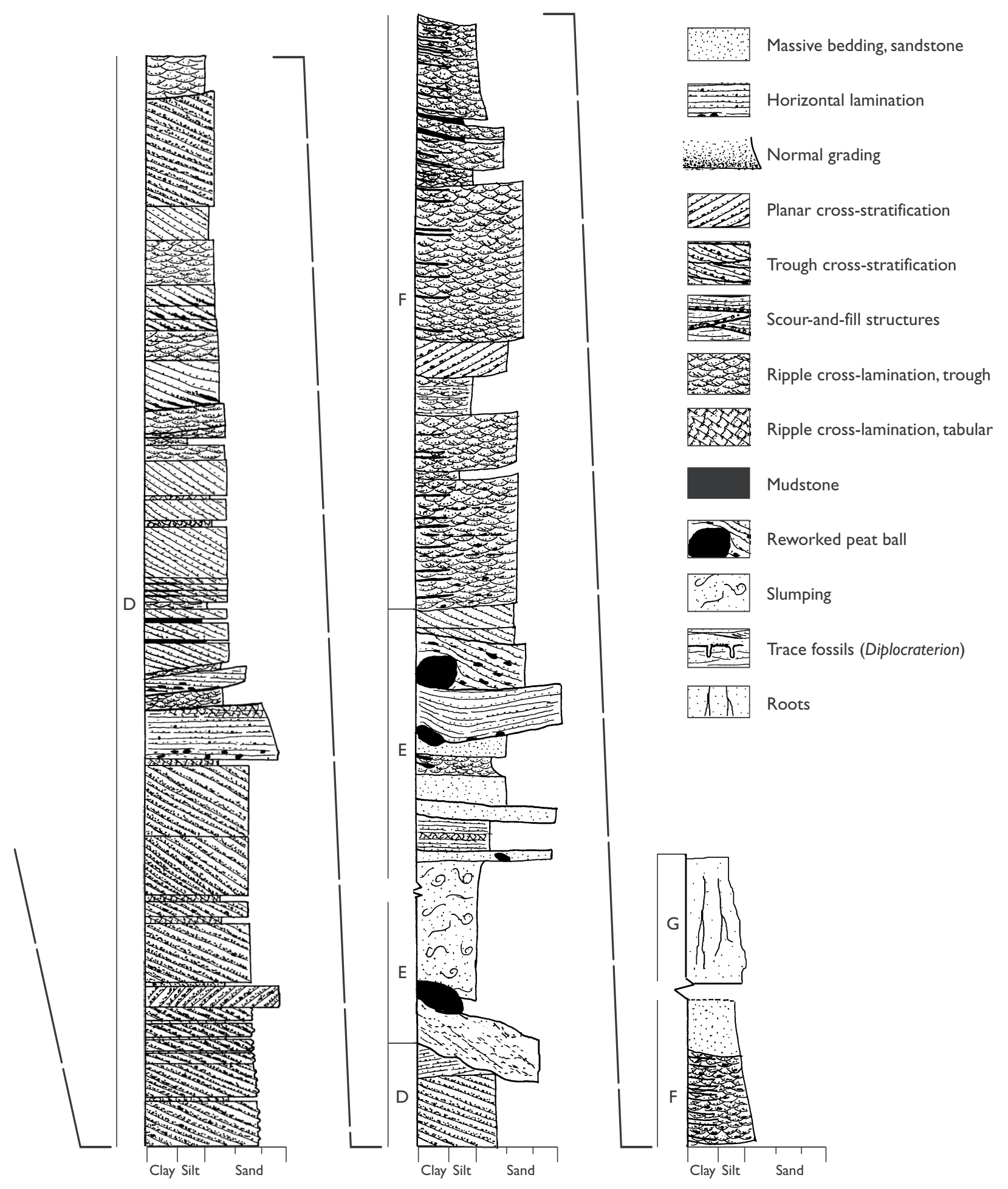

F. Surlyk (personal communication 1998) considers the Glass Sand Member to represent high-energy tidallydominated environments ranging from tidal inlets and open estaurine conditions with large tidal sand bars, flats and channels to marine foreshore; the upper boundary of the member is interpreted to record a major relative sea-level fall. In contrast, J. Johansson and L.
Adrielsson (personal communication 1998) investigated a section through the Glass Sand Member and concluded that fluvial deposits prevail throughout, with few signs (e.g. trace fossils) indicating proximity to the marine realm (Fig. 5). These workers thus proposed that the succession probably represents the fluvial-dominated part of a delta plain. 


\section{Annero Formation}

\section{Stratigraphy and distribution}

From below, the Annero Formation (Fig. 2) is subdivided into the Fortuna Marl, the Fyledalen Clay, the Nytorp Sand, and the Vitabäck Clay. Based on biostratigraphy (foraminifera, ostracodes and palynomorphs), the Fortuna Marl is referred to the Bathonian-Oxfordian, the Fyledalen Clay to the Oxfordian-Kimmeridgian, the Nytorp Sand to the Kimmeridgian-Tithonian, and the Vitabäck Clays to the Tithonian-Berriasian (Christensen 1968; Norling 1972, 1981; Erlström et al. 1991). Sediments referred to the Annero Formation are found in western Skåne including the Ängelholm Trough, in the Fyledalen Fault Zone and in the Vomb Trough, and have been described by Norling $(1972,1981)$ and Erlström et al. (1991). The Fortuna Marl is restricted to the LandskronaKävlinge area, where it has a thickness of up to $10 \mathrm{~m}$ (Guy-Ohlson \& Norling 1988). The Fyledal Clay is about $30 \mathrm{~m}$ thick in the Helsingborg-Landskrona area and in the Ängelholm Trough, and more than $55 \mathrm{~m}$ thick (estimated to $140 \mathrm{~m}$ ) in the Fyledalen section, and $24 \mathrm{~m}$ thick in the Vomb Trough. The Nytorp Sand is 20-25 m thick in the Helsingborg-Landskrona area, $20 \mathrm{~m}$ thick in the Fyledalen section and $5 \mathrm{~m}$ thick in the Assmåsa borehole. The Vitabäck Clay is 20-25 m thick in the Ängelholm and Vomb Troughs, more than $5 \mathrm{~m}$ thick in the Landskrona-Helsingborg area, and more than $34 \mathrm{~m}$ thick in the Fyledalen section (Norling 1981).

\section{Lithology and petrography}

The thin Fortuna Marl has only been observed in a few drill cores of limited quality, and sedimentological information is therefore minimal. The strata comprise sandstone, carbonate-rich siltstones and mudstones, with a marine microfauna (Guy-Ohlson \& Norling 1988).

The Fyledal Clay is characterised by a uniform succession of greenish and organic-rich clays, interrupted by thin silt and sand beds (Guy-Ohlson \& Norling 1988; Erlström et al. 1991). The sediment displays, on the one hand, continental and freshwater indicators such as rootlet beds, oligohaline-mesohaline ostracodes and caliche nodules. On the other hand, marine indicators are also recorded, such as calcareous foraminifera. Erlström et al. (1991) thus suggested that deposition mainly took place on a muddy coastal plain, with stagnant ponds (lagoons). Fining-upwards sandstone wedges $(<1 \mathrm{~m}$ thick) with erosional bases have been observed in the Fyledal Clay at the Eriksdal quartz sand quarry. These include gravel with rip-up mud clasts and mollusc shells at the base, as well as reworked glauconite in their higher parts. The sand wedges have been interpreted as washover fan deposits (Erlström et al. 1991).

The occurrence of Upper Jurassic evaporites and euryhaline biota are very few, but may be of particular significance. Whereas the caliche nodules are well preserved, it is unclear if the gypsum is of primary origin. In any case, these represent the only signs of aridity in the Jurassic successions of Skåne. Hence, Skåne may have been only marginally influenced by the Late Jurassic north-eastwards migration of the arid climate zone of western and central Pangea (Hallam 1994).

The Nytorp Sand is not accessible for facies analysis. However, due to its stratigraphic position between the Fyledal Clay and the similar Vitabäck Clay, Erlström et al. (1991) inferred deposition in a back-barrier environment.

The Vitabäck Clay, which straddles the JurassicCretaceous boundary, is primarily known from lithological and palaeontological investigations of samples, as continuous sections are not available. The mud-dominated formation shows similarities to the Fyledal Clay, only with a slightly higher content of sandy beds. Palynomorphs, ostracodes and molluscs indicate nonmarine conditions with brackish marine influence, and deposition probably took place on a muddy coastal plain (Ekström 1985; Erlström et al. 1991).

\section{Jurassic volcanism and pyroclastic deposits}

In central Skåne, numerous Mesozoic basaltic necks occur (Norin 1933). The basalts are typically vitrophyric with columnar structures, and undersaturated with respect to silica (see Wikman \& Sivhed 1993 and Wikman et al. 1993 for reviews). K-Ar datings of the basalts indicate Bathonian and Aptian ages (Printzlau \& Larsen 1972; Klingspor 1976). Recent palaeomagnetic datings, however, have yielded older, Toarcian-Aalenian ages (Bylund \& Halvorsen 1993).

Despite the abundant volcanic necks in Skåne, the distribution of pyroclastic deposits appears surprisingly limited. This, and the abundance of lithified magma spray droplets, may indicate a hawaiian or strombolian type of eruptive activity, i.e. rather passive eruptions of low-viscosity basaltic magma (Scarth 1994). Only locally, around the volcanic necks of central Skåne, up to $50 \mathrm{~m}$ thick volcanic tuffites occur, which presently are exposed 
in two sections (Norling et al. 1993). No correlative pyroclastic beds have yet been identified in sedimentary basins surrounding central Skåne.

The tuffites are dominated by lapilli, which in thin section show clusters of tiny spherical condensed glass particles which are now diagenetically transformed to clay minerals and other relatively stable minerals. Other constituents comprise rare volcanic bombs (typically $5-10 \mathrm{~cm}$ in cross-section), angular and rounded gneiss boulders (typically $5-15 \mathrm{~cm}$ in cross-section), probably from the sidewall, scattered detrital quartz grains, and pieces of fossil wood, including large logs. Palynological dating of the tuffites has yielded an age at the Early-Middle Jurassic boundary (Tralau 1973). In central Skåne, the volcanic intrusions have probably had a profound effect on the diagenesis of the Lower Jurassic arenites (see below).

\section{Diagenesis, thermal history and petroleum potential}

In the Jurassic strata of Skåne, most diagenetic properties were obtained rather soon after deposition, i.e. eodiagenetically. Hence, the sediments were influenced by surficial features such as climate, groundwater and pedogenic processes. Due to only moderate burial temperatures, burial diagenetic features are less pronounced (Ahlberg 1996). A low thermal impact has been confirmed by Guy-Ohlson (1989; personal communication 1994) who observed low Thermal Alteration Index (TAI) values of palynomorphs (around 3) throughout the Jurassic of Skåne. The Rhaetian-Hettangian Höör Sandstone in central Skåne is an exception to this. As revealed by cathodoluminescence microscopy and fluid inclusion analysis, the Höör Sandstone was subjected to flushing of hot hypersaline brines, which probably were released in association with the Early-Middle Jurassic volcanic events (Ahlberg 1994).

The organic content of the Jurassic strata in Skåne is typically dominated by gas prone kerogen (type III), which is below, or at the onset of, thermal maturity (Ahlberg 1996). As the burial heat was insufficient, hydrocarbon maturity can only have been achieved locally, possibly in association with faulting and volcanic activity. The faults, however, were also potential escape routes for migrating hydrocarbons (Ahlberg 1996; Ahlberg \& Olsson 2001).

\section{References}

Ahlberg, A. 1990: Provenance, stratigraphy, palaeoenvironments and diagenesis of the Lower Jurassic strata in the Helsingborg railway tunnel, southern Sweden, 2, 54 pp. Unpublished licentiate thesis, Lund University, Sweden.

Ahlberg, A. 1994: Deposition and diagenesis of the RhaetianHettangian succession (Triassic-Jurrassic) in southern Sweden: a synthesis. Lund Publications in Geology 123, 16 pp.

Ahlberg, A. 1996: Petroleum in the Mesozoic of Sweden - why not? Geologiska Föreningens i Stockholm Förhandlingar 118 , 114-115.

Ahlberg, A. \& Olsson, I. 2001: Petroleum assessment of the Mesozoic succession in the Höllviken Graben and on the Skurup Platform, southern Sweden. Geologiska Föreningens i Stockholm Förhandlinger 123, 85-95.

Allen, J.R.L. \& Wright, V.P. 1989: Palaeosols in siliciclastic sequences. University of Reading, Postgraduate Research Institute of Sedimentology, Short Course Notes 1, 97 pp.

Antevs, E. 1919: Die Liassische Flora des Höörsandsteins. Kungliga Svenska Vetenskapsakademins Handlingar (Stockholm) 59(8), 71 pp.

Arndorff, L. 1994: Upper Triassic and Lower Jurassic palaeosols from southern Scandinavia. Lund Publications in Geology 116, $30 \mathrm{pp}$

Bergström, J., Holland, B., Larsson, K., Norling, E. \& Sivhed, U. 1982: Guide to excursions in Scania. Sveriges Geologiska Undersökning Serie Ca 54, 95 pp.

Berthelsen, A. 1992: Tectonic evolution of Europe: from Precambrian to Variscan Europe. In: Blundell, D., Freeman, R. \& Mueller, S. (eds): A continent revealed. The European Geotraverse, 153-163. Cambridge: Cambridge University Press.

Bölau, E. 1952: Neue Fossilfunde aus dem Rhät Schonens und ihre palaeogeographisch-ökologische Auswartung. Geologiska Föreningens i Stockholm Förhandlingar 74, 44-50.

Bölau, E. 1959: Der Südwest- und Südoststrand des Baltischen Schildes (Schonen und Ostbaltikum). Geologiska Föreningens i Stockholm Förhandlingar 81, 167-230.

Brotzen, F. 1950: De geologiska resultaten från borrningarna vid Höllviken. Del II. Undre Kritan och Trias. Sveriges Geologiska Undersökning Serie C 505, 48 pp.

Bylund, G. \& Halvorsen, E. 1993: Palaeomagnetic study of Mesozoic basalts from Scania, southernmost Sweden. Geophysical Journal International 114, 138-144.

Christensen, O.B. 1968: Some deposits and microfaunas from the Upper Jurassic in Scania. With new species of ostracodes. Sveriges Geologiska Undersökning Serie C 632, 46 pp.

Curtis, C.D. \& Coleman, M.L. 1986: Controls on the precipitation of early diagenetic calcite, dolomite and siderite concretions in complex depositional sequences. In: Gautier, D.L. (ed.): Roles of organic matter in sediment diagenesis. Society of Economic Paleontologists and Mineralogists Special Publication 38, 23-34.

Ekström, J. 1985: Stratigrafisk och faunistisk undersökning av vitabäckslerorna i Skåne. Examination paper in geology, 18 pp. Unpublished. Lund Universitet 9, Sverige.

Erlström, M., Guy-Ohlson, D. \& Sivhed, U. 1991: Upper Jurassic - Lower Cretaceous petrography and stratigraphy at Eriksdal, 
Scania, southern Sweden. Sveriges Geologiska Undersökning Serie Ca 78, 59 pp.

Erlström, M., Guy-Ohlson, D. \& Sivhed, U. 1994: Palaeoecology and sedimentary environments of the Jurassic-Cretaceous transition beds in Sweden. Geobios Special Publication 17, 671-678.

Erlström, M., Thomas, S.A., Deeks, N. \& Sivhed, U. 1997: Structure and tectonic evolution of the Tornquist Zone and adjacent sedimentary basins in Scania and the southern Baltic Sea area. Tectonophysics 271, 191-215.

EUGENO-S Working Group 1988: Crustal structure and tectonic evolution of the transition between the Baltic Shield and the North German Caledonides (the EUGENO-S Project). Tectonophysics 150, 253-348.

Frandsen, N. \& Surlyk, F. 2003: An offshore transgressive-regressive mudstone-dominated succession from the Sinemurian of Skåne, Sweden. In: Ineson, J.R. \& Surlyk, F. (eds): The Jurassic of Denmark and Greenland. Geological Survey of Denmark and Greenland Bulletin 1, 543-554 (this volume).

Gierlinski, G. \& Ahlberg, A. 1993: Late Triassic and Early Jurassic dinosaur footprints in the Höganäs Formation, southern Sweden. Ichnos 2, 99-105.

Guy-Ohlson, D. 1971: Palynological investigations in the Middle Jurassic of the Vilhelmsfält boring, southern Sweden. Publications from the Institutes of Mineralogy, Palaeontology and Quaternary Geology, University of Lund 168, 104 pp.

Guy-Ohlson, D. 1981: Rhaeto-Liassic palynostratigraphy of the Valhall Bore No. 1, Scania. Geologiska Föreningens i Stockholm Förhandlingar 103, 233-248.

Guy-Ohlson, D. 1986: Jurassic palynology of the Vilhelmsfält Bore No. 1, Scania, Sweden. Toarcian-Aalenian, 127 pp. Stockholm: Section of Palaeobotany, Swedish Museum of Natural History.

Guy-Ohlson, D. 1989: Spore and pollen assemblage zonation of Swedish Bajocian and Bathonian sediments. In: Batten, D.J. \& Keen, M.C. (eds): North-west European micropalaeontology and palynology, 70-91. London: British Micropalaeontological Society.

Guy-Ohlson, D. \& Norling, E. 1988: Upper Jurassic litho- and biostratigraphy of NW Scania, Sweden. Sveriges Geologiska Undersökning Serie Ca 72, 37 pp.

Hadding, A. 1933: Den järnmalmsförande lagerserien i sydöstra Skåne. Sveriges Geologiska Undersökning Serie C 376, 39 pp.

Hallam, A. 1994: Jurassic climates as inferred from the sedimentary and fossil record. In: Allen, J.R.L. et al. (eds): Palaeoclimates and their modelling, with special reference to the Mesozoic Era, 79-88. London: Chapman \& Hall.

Heikoop, J.M., Tsujita, C.J., Risk, M.J., Tomascik, T. \& Mah, A.J. 1996: Modern iron ooids from a shallow marine volcanic setting; Mahengetang, Indonesia. Geology 24, 759-762.

Klingspor, I. 1976: Radiometric age-determinations of basalts, dolerites and related syenite in Skåne, southern Sweden. Geologiska Föreningens i Stockholm Förhandlingar 98, 195-216.

Koch, J.-O. 1979: Sen-Palaeozoisk-Mesozoisk bassinudvikling i det danske område og Mellem og Øvre Jurassisk sedimentation ved Eriksdal i Skåne, 97 pp. Unpublished cand. scient. thesis, Københavns Universitet, Danmark.

Koppelhus, E.B. 1995: Jurassic palynostratigraphy of Bornholm, Baltic Sea, Denmark. In: Michelsen, O. (ed.): Proceedings of the 2nd symposium on marine geology: geology of the North Sea and Skagerrak, Aarhus Universitet, 1993. Danmarks Geologiske Undersøgelse Serie C 12, 137-144.

Larsson, K., Ahlberg, A., Guy-Ohlsson, D., Arndorff, L. \& Vajda, V. 1994: The subsurface Mesozoic geology of SW Scania, southern Sweden - well descriptions and annotations on stratigraphy, structural geology, depositional environments and diagenesis, 49 pp. Unpublished report, Sveriges Geologiska Undersökning, Sverige.

Liboriussen, J., Ashton, P. \& Tygesen, T. 1987: The tectonic evolution of the Fennoscandian Border Zone in Denmark. In: Ziegler, P.A. (ed.): Compressional intra-plate deformations in the Alpine Foreland. Tectonophysics 137, 21-29.

Lund, J. 1977: Rhaetic to Lower Liassic palynology of the onshore south-eastern North Sea Basin. Danmarks Geologiske Undersøgelse II. Række 109, 129 pp.

Manspeizer, W. 1994: The break-up of Pangea and its impact on climate: Consequences of Variscan-Alleghanide orogenic collapse. In: Klein, G.D. (ed.): Palaeoclimate, tectonics and sedimentation during accretion, zenith, and break-up of a supercontinent. Geological Society of America Special Paper 288, 169-185.

Michelsen, O. \& Nielsen, L.H. 1993: Structural development of the Fennoscandian Border Zone, offshore Denmark. Marine and Petroleum Geology 10, 124-134.

Moberg, J.C. 1888: Om Lias i sydöstra Skåne. Sveriges Geologiska Undersökning Serie C 99, 86 pp.

Möller, H.J. \& Halle, T.G. 1913: The fossil flora of the coal-bearing deposits of south-eastern Scania. Kungliga Svenska Vetenskapsakademins Handlingar (Stockholm) 13, 45 pp.

Nielsen, L.H. 1994: Øvre Trias - Mellem Jura aflejringerne i det Danske Bassin. Dansk Geologisk Forening 100 års jubilæumssymposium - Geologi på tværs af det Danske Rige. Copenhagen, 19-20 November 1993. Abstracts, 35-38.

Nielsen, L.H. 2003: Late Triassic - Jurassic development of the Danish Basin and the Fennoscandian Border Zone, southern Scandinavia. In: Ineson, J.R. \& Surlyk, F. (eds): The Jurassic of Denmark and Greenland. Geological Survey of Denmark and Greenland Bulletin 1, 459-526 (this volume)

Nilsson, P. 1992: Lateritisering - en process som kan ha orsakat Fe-anrikning i Skånes Rät-Lias lager. Lund University, examination paper in geology $\mathbf{4 4}, 40 \mathrm{pp}$.

Norin, R. 1933: Mineralogische und petrographische Studien an den Basalten Schonens. Geologiska Föreningens i Stockholm Förhandlingar 55, 101-149.

Norling, E. 1972: Jurassic stratigraphy and foraminifera of western Scania, southern Sweden. Sveriges Geologiska Undersökning Serie Ca 47, 120 pp.

Norling, E. 1981: Upper Jurassic and Lower Cretaceous geology of Sweden. Geologiska Föreningens i Stockholm Förhandlingar 103, 253-269.

Norling, E. 1982: Längs stigar mot det förgångna - berggrundsgeologiskt strövtåg i Kullabygden. Skånes Naturvårdsförbunds Årsskrift, Lund 69, 21-40.

Norling, E. \& Bergström, J. 1987: Mesozoic and Cenozoic tectonic 
evolution of Scania, southern Sweden. In: Ziegler, P.A. (ed.): Compressional intra-plate deformations in the Alpine Foreland. Tectonophysics 137, 7-19.

Norling, E. \& Skoglund, R. 1977: Der Südwestrand der Osteuropäischen Tafel im Bereich Schwedens. Zeitschrift für Angewandte Geologie 23, 449-458.

Norling, E. \& Wikman, H. 1990: Beskrivning till berggrundskartan Höganäs NO/Helsingborg NV. Sveriges Geologiska Undersökning Serie Af 129, 123 pp.

Norling, E., Ahlberg, A., Erlström, M. \& Sivhed, U. 1993: Guide to the Upper Triassic and Jurassic geology of Sweden. Sveriges Geologiska Undersökning Serie Ca 82, 71 pp.

Pieńkowski, G. 1991a: Eustatically-controlled sedimentation in the Hettangian-Sinemurian (Early Jurassic) of Poland and Sweden. Sedimentology 38, 503-518.

Pieńkowski, G. 1991b: Liassic sedimentation in Scania, southern Sweden: Hettangian-Sinemurian of the Helsingborg area. Facies 24, 39-86.

Posamentier, H.W., Allen, G.P., James D.P. \& Tesson, M. 1992: Forced regressions in a sequence stratigraphic framework; concepts, examples, and exploration significance. American Association of Petroleum Geologists Bulletin 76, 1687-1709.

Printzlau, I. \& Larsen, O. 1972: K-Ar age determinations on alkaline olivine basalts from Skåne, south Sweden. Geologiska Föreningens i Stockholm Förhandlingar 94, 259-269.

Reyment, R. 1959: On Liassic ammonites from Skåne, southern Sweden. Stockholm Contributions in Geology 2(6), 103-157.

Reyment, R. 1969: Upper Sinemurian (Lias) at Gantofta, Skåne. Geologiska Föreningens i Stockholm Förhandlingar 91, 208-216.

Rolle, F., Koch, J.-O., Frandsen, N. \& Surlyk, F. 1979: Jurassic environments in the Fenno-Scandian Border Zone. Symposium on 'Sédimentation jurassique W. européen'. Association Sedimentologie Francais Publication Spéciale 1, 15-31.

Scarth, A. 1994: Volcanoes, 273 pp. London: University College London Press.

Sellwood, B.W. 1972: Tidal flat sedimentation in the Lower Jurassic of Bornholm, Denmark. Palaeogeography, Palaeoclimatology, Palaeoecology 11, 93-106.

Shanley, K.W. \& McCabe, P.J. 1994: Perspective on the sequence stratigraphy of continental strata. American Association of Petroleum Geologists Bulletin 78, 544-568.

Sivhed, U. 1980: Lower Jurassic ostracodes and stratigraphy of western Skåne, southern Sweden. Sveriges Geologiska Undersökning Serie Ca 50, 84 pp.

Sivhed, U. 1984: Litho- and biostratigraphy of the Upper Triassic - Middle Jurassic in Scania, southern Sweden. Sveriges Geologiska Undersökning Serie C 806, 31 pp.

Sivhed, U. \& Wikman, H. 1986: Beskrivning till berggrundskartan Helsingborg SV. Sveriges Geologiska Undersökning Serie Af 149, 108 pp.

Surlyk, F. \& Noe-Nygaard, N. 1986: Hummocky cross-stratification from the Lower Jurassic Hasle Formation of Bornholm, Denmark. Sedimentary Geology 46, 259-273.

Terwindt, J.H.J. 1981: Neap-spring tide sequences of intertidal shoal deposits in a mesotidal estuary. Sedimentology 28, 151-170.
Thomas, S.A. \& Deeks, N. 1994: Seismic evidence for inversion tectonics in the strike-slip regime of the Tornquist Zone, southern Baltic Sea. Zeitschrift für Geologische Wissenschaften 22(1/2), 33-45.

Thomas, S., Sivhed, U., Erlström, M. \& Seifert, M. 1993: Seismostratigraphy and structural framework of the SW Baltic Sea. Terra Nova 5, 364-374.

Thybo, H., Abramovitz, A., Lassen, F. \& Schjöth, F. 1994: Deep structure of the Sorgenfrei-Tornquist Zone interpreted from BABEL seismic data. Zeitschrift für Geologische Wissenschaften 22(12), 3-17.

Tralau, H. 1966: Botanical investigations of the fossil flora of Eriksdal in Fyledalen, Scania. Sveriges Geologiska Undersökning Serie C 611, 36 pp.

Tralau, H. 1968: Botanical investigations into the fossil flora of Eriksdal in Fyledalen, Scania. II: The middle Jurassic microflora. Sveriges Geologiska Undersökning Serie C 633, 185 pp.

Tralau, H. 1973: En palynologisk åldersbestämning av vulkanisk aktivitet i Skåne. Fauna och Flora 68, 121-176.

Troedsson, G. 1940: Om Höörs sandsten. Geologiska Föreningens i Stockholm Förhandlingar 62, 245-283.

Troedsson, G. 1948: Om fynd af rätiska fossil i Skåne. Geologiska Föreningens i Stockholm Förhandlingar 70, 528-550.

Troedsson, G. 1950: On rhythmic sedimentation in the RhaeticLiassic beds of Sweden. International Geological Congress. 'Report of the Eighteenth Session, Great Britain 1948' IV, 64-72.

Troedsson, G. 1951: On the Höganäs Series of Sweden (RhaetoLias). Lunds Universitet Årsskrift Ny Följd 2 47(1), 269 pp.

Tyge, P. 1990: Palaeotidale processer i en mundingsbarre association fra den Nedre Jurassiske Galgeløkke Member, Bornholm. Dansk Geologisk Forenings Årsskrift 1987-1989, 37-40.

Vejbæk, O.V. 1985: Seismic stratigraphy and tectonics of sedimentary basins around Bornholm, southern Baltic. Danmarks Geologiske Undersøgelse Serie A 8, 30 pp.

Vejbæk, O.V. 1997: Dybe strukturer i danske sedimentære bassiner. Geologisk Tidsskrift 4, 1-31.

Vejbæk, O.V., Stouge, S. \& Poulsen, K.D. 1994: Palaeozoic tectonic and sedimentary evolution and hydrocarbon prospectivity in the Bornholm area. Danmarks Geologiske Undersøgelse Serie A 34, 23 pp.

Vossmerbäumer, H. 1969: Paläoökologische Ausdeutung fossiler Wurzelböden. Geologiska Föreningens i Stockholm Förhandlingar 91, 112-126.

Vossmerbäumer, H. 1970: Untersuchungen zur Bildungsgeschichte des Unteren Lias in Schonen (Schweden). Geologica et Palaeontologica 4, 167-193.

Wikman, H. \& Sivhed, U. 1993: Beskrivning till berggrundskartan Kristianstad SV. Sveriges Geologiska Undersökning Serie Af 155, 106 pp.

Wikman, H., Bergström, J. \& Sivhed, U. 1993: Beskrivning till berggrundskartan Helsingborg SO. Sveriges Geologiska Undersökning Serie Af 180, 114 pp.

Ziegler, P.A. 1990: Geological atlas of western and central Europe, 2nd edition, 239 pp. Amsterdam: Elsevier for Shell Internationale Petroleum Maatschappij. 
